\title{
Effects of long-term use of HAART on oral health status of HIV- infected subjects
}

\author{
Wipawee Nittayananta ${ }^{1}$, Sineepat Talungchit ${ }^{2}$, Sutep Jaruratanasirikul ${ }^{3}$, Kachornsakdi \\ Silpapojakul ${ }^{3}$, Panthip Chayakul ${ }^{3}$, Ampaipith Nilmanat ${ }^{4}$, and Nannapat Pruphetkaew ${ }^{1}$ \\ ${ }^{1}$ Epidemiology Unit, Faculty of Medicine, Prince of Songkla University, Hat Yai, Thailand \\ ${ }^{2}$ Department of Oral Surgery and Oral Medicine, Faculty of Dentistry, Srinakharinwirot University, \\ Bangkok, Thailand ${ }^{3}$ Department of Medicine, Faculty of Medicine, Prince of Songkla University, \\ Hat Yai, Thailand ${ }^{4}$ Division of Medicine, Hat Yai Regional Hospital, Hat Yai, Thailand
}

\begin{abstract}
BACKGROUND-The aim of this study was to determine the effects of long-term use of highly active antiretroviral therapy (HAART) on oral health status of HIV-infected subjects.
\end{abstract}

\begin{abstract}
METHODS-Oral examination and measurement of saliva flow rate of both unstimulated and wax-stimulated whole saliva were performed in HIV-infected subjects with and without HAART, and in non-HIV individuals. The following data were recorded; duration and risk of HIV infection, type and duration of HAART, CD4 cell count, viral load, presence of orofacial pain, oral dryness, oral burning sensation, oral lesions, cervical caries, and periodontal pocket. Multiple logistic regression analysis was performed to determine the effects of long-term use of HAART on oral health status of HIV-infected subjects. RESULTS: One hundred and fifty-seven HIV-infected subjects -99 on HAART (age range 23-57 years, mean 39 years) and 58 not on HAART (age range 20-59 years, mean 34 years) - and 50 non-HIV controls (age range 19-59 years, mean 36 years) were enrolled. The most common HAART regimen was 2 NRTI + 2 NNRTI. HIV-infected subjects without HAART showed greater risks of having orofacial pain, oral dryness, oral lesions, and periodontal pockets than those with short-term HAART $(P<0.01)$. The subjects with longterm HAART were found to have a greater risk of having oral lesions than those with short-term HAART $(P<0.05)$. The unstimulated and stimulated salivary flow rates of the subjects with HAART were significantly lower than in those without HAART $(P<0.05)$.
\end{abstract}

CONCLUSION-We conclude that long-term HAART has adverse effects on oral health status of HIV-infected subjects.

\section{Keywords}

HAART; HIV; oral health; oral lesion; risk factor; salivary flow rate

\section{Introduction}

Highly active antiretroviral therapy (HAART) has become a standard treatment for HIV infection. It induces a marked reduction in viral load and increase in the $\mathrm{CD} 4^{+}$cell count (1) leading to a declination in morbidity and mortality of HIV-infected subjects (2). At present,

(C) 2010 John Wiley \& Sons A/S · All rights reserved

Correspondence: Prof. Dr. Wipawee Nittayananta, Epidemiology Unit, Faculty of Medicine, Prince of Songkla University, Hat Yai, Songkhla 90110, Thailand. Tel: 6674451 165, Fax: 6674212 900, wipawee.ni@psu.ac.th. 
HAART includes more than 30 different drugs of six separate classes: nucleoside reverse transcriptase inhibitors (NRTIs), non-nucleoside reverse transcriptase inhibitors (NNRTIs), protease inhibitors (PIs), fusion inhibitors, entry inhibitors, and HIV integrase inhibitors (3).

In HAART therapy, a range of different combinations of drugs are used, and each drug combination has advantages and disadvantages. In general, there are three commonly used combinations: 1 NNRTI + 2 NRTI; 1 or 2 PIs + 2 NRTIs; and 3 NRTIs (3). They are administered simultaneously to bring about a sustained block in viral replication and restore immune function, as well as to minimize viral resistance to the drugs (4).

Before the HAART era, some oral lesions including oral candidiasis (OC) and oral hairy leukoplakia (OHL) were commonly observed among HIV-infected individuals both in developed and developing countries (5-10). The introduction of HAART has contributed to a global reduction in oral lesions in adults and children (11-13). A decreased prevalence of HIV-related oral lesions of 10-50\% following the advent of HAART has been reported (11, 14-16). However, the impact of long-term use of HAART on oral health status of HIVinfected subjects is poorly documented.

Salivary glands are affected by HIV infection. HIV-infected subjects show decreased salivary flow rates and often complain of dry mouth or xerostomia (17-19). Previous studies reported salivary gland hypofunction and xerostomia in 2-10\% of HIV-infected individuals $(8,17,20)$. The presence of oral symptoms has a significant impact on health-related quality of life $(21,22)$. However, it is not well established if long-term use of HAART results in any adverse effects on oral health that may affect the patients' quality of life. In addition, it is not clear about the nature and significance of HIV salivary gland disease, and whether HIVinfected individual on HAART is at risk of increased dental caries.

Thailand began a national HAART program in 2000 (23). So far, no report is available on changes in the pattern of HIV-related oral lesions among Thai people with HIV infection in the HAART era. In addition, the effects of long-term use of HAART on their oral health remain unknown. The objectives of this study were to determine: (i) the oral health status of HIV-infected subjects in the HAART era compared with non-HIV controls and (ii) the effects of long-term use of HAART on oral health status of HIV-infected individuals.

\section{Materials and methods}

A cross-sectional study was performed in HIV-infected subjects who came to receive HAART at the Internal Medicine Clinic at Songklanagarind Hospital and Hat Yai Regional Hospital in southern Thailand. The inclusion criteria of subjects enrolled were: (i) seropositive for antibody to HIV when tested by a particle agglutination test for antibodies to HIV (SERODIA ${ }^{\circledR}$ HIV, Fujirebio Inc., Shinjuku-ku, Tokyo, Japan) and enzyme-linked immunosorbent assay (ELISA) (Enzygnost ${ }^{\circledR}$ Anti-HIV 1/2 Plus, Behring, Behringwerke AG, Marburg, Germany), (ii) currently taking HAART, and (iii) willing to participate in the study. The exclusion criteria were: (i) HIV-infected subject with history of local radiation therapy on head and neck region and (ii) severely ill HIV-infected subject who could not cooperate with the study procedures of saliva collection. HIV-infected individuals who came to those hospitals, but had not yet started HAART, and non-HIV-infected volunteers were asked to participate as controls.

\section{Ethics}

The study protocol was approved by the research committee at the Prince of Songkla University, and at the Ministry of Public Health. All information about the patients and their identity was anonymous. Subjects were given both verbal and written information about the 
nature of the study, and written consent was obtained. Subjects were allowed to leave the study at any time during the procedures.

\section{Clinical examination}

History taking and oral examination were performed in HIV subjects with and without HAART and in non-HIV individuals. Clinical diagnosis of HIV-related oral lesions was made according to the criteria proposed by the EC-Clearinghouse (24). Unstimulated salivary flow rate using the draining method and paraffin-stimulated salivary flow rate were measured.

The following data were recorded: duration of HIV infection, risk group of HIV infection, use of HAART, $\mathrm{CD}^{+}$cell count, presence of orofacial pain, presence of oral lesions, presence of cervical caries, periodontal health status, bleeding on probing, feeling of oral dryness, and oral burning sensation.

\section{Measurement of saliva flow rate}

A measurement of saliva flow rate was conducted only in the morning between 9:00 ам and 12:00 Ам. All subjects were asked to rinse their mouths with $0.9 \%$ normal saline and spit out, and thereafter swallow before starting the collection procedure. The measurement comprised unstimulated and wax-stimulated whole saliva flow rates by the draining technique as described in detail by Navazesh and Christensen (25). In brief: unstimulated whole saliva was collected over $15 \mathrm{~min}$. The subjects were instructed to lean their body forward and drain their saliva passively into a plastic cup, pre-weighed using a digital scale (OHAUSE, USA), for $5 \mathrm{~min}$. They were asked to repeat the procedure two more times in two other preweighed plastic cups, and saliva was collected for $5 \mathrm{~min}$. One gram of saliva is assumed to be equal to $1 \mathrm{ml}$ of saliva. The unstimulated salivary flow rate $(\mathrm{ml} / \mathrm{min})$ was calculated by dividing the mean weight of the three collected saliva samples by time ( $5 \mathrm{~min}$ ).

Stimulated saliva was collected over 6 min. The subjects were instructed to chew a cube of 1 $\mathrm{g}$ paraffin without taste with a frequency of 25 times per minute for $2 \mathrm{~min}$. They were instructed not to swallow saliva during the course of saliva collection. Persons with denture were asked to chew the cube of paraffin without removal of their denture. The patients passively drained their saliva into a pre-weighed plastic cup four times at $30 \mathrm{~s}$ interval. They were asked to repeat the procedure two more times in two other pre-weighed plastic cups, and saliva was collected for $2 \mathrm{~min}$. The stimulated saliva flow rate $(\mathrm{ml} / \mathrm{min})$ was calculated by dividing the mean weight of the three collected saliva samples and by time ( $2 \mathrm{~min})$.

\section{Statistical analysis}

Descriptive statistics were used to analyze the data, breaking down of subjects by status of HIV test and duration of HAART received. Chi-square test was employed to explore the possible association between oral health status, oral lesions and HIV /HAART status. Finally, as the risk for oral health problem may be influenced by the duration of HIV infection, levels of CD4 count, and smoking and drinking behaviors, linear and logistic regression, respectively, were used to analyze the relationship between salivary flow rate and oral health problems with duration of HAART use. Statistical significance was set at $P=0.05$.

\section{Results}

\section{Subjects and use of HAART}

Ninety-nine HIV-infected subjects receiving HAART (age range 23-57 years, mean age 39 years), 58 not receiving HAART (age range 20-59 years, mean age 34 years), and 50 non- 
HIV individuals (age range 19-59 years, mean age 36 years) were enrolled. Most HIVinfected subjects who were on HAART did not receive PI-based regimen $(n=84,85 \%)$. Different combinations of HAART used among HIV-infected subjects were 2 NRTIs +1 NNRTI $(n=82,83 \%), 2$ NRTIs +2 PIs $(n=7,7 \%), 2$ NRTIs +1 PI $(n=3,3 \%)$, and others $(n=7,7 \%)$. Those who had been taking ART $<3$ years were classified as a group with shortterm use of HAART and those who had been taking HAART for $\geq 3$ years were classified as a group with long-term use of HAART. Various characteristics of the subjects and controls are shown in Table 1.

\section{Prevalence of oral lesions}

Prevalence of oral lesions among HIV-infected subjects with and without HAART and nonHIV individuals is shown in Table 2. Hyperpigmentation was the most common oral lesion seen in all groups. Only two and one HIV-infected subjects who received HAART showed OC and OHL, respectively. Of interest, no oral warts were observed among the subjects.

\section{Oral health status of HIV-infected subjects and non-HIV controls}

Oral health status including the presence of orofacial pain, oral dryness, oral burning sensation, presence of oral lesions, cervical caries, periodontal pocket depth, gingival bleeding on probing, and salivary flow rates of both unstimulated and stimulated saliva was analyzed according to HIV status and HAART status. With respect to HIV status, prevalence of oral lesions was found to be statistically significantly higher in HIV-infected subjects than in non-HIV controls (Chi-square test, $P<0.001$ ). Salivary flow rates of both unstimulated and stimulated saliva in HIV-infected subjects were statistically significantly lower than in non-HIV controls (Chi-square test, $P<0.001$ ). Oral health status of HIVinfected subjects was also found to be statistically significant difference due to HAART status (Table 3).

\section{Effects of long-term use of HAART on oral health status of HIV-infected subjects}

Effects of long-term use of HAART on oral health status of HIV-infected subjects were analyzed by multiple logistic regression analysis. After controlling for duration of HIV infection, $\mathrm{CD}^{+}$cell counts, smoking habits, and alcohol consumption, HIV-infected subjects with long-term use of HAART were found to have a greater risk of developing oral lesions than those with short-term use of HAART $(P<0.05)$ (Table 4$)$. HIV-infected subjects without HAART showed greater risks of having orofacial pain, oral dryness, oral lesions, and periodontal pockets than those with short-term use of HAART $(P<0.01)$. In addition, HIV-infected subjects with long-term use of HAART showed a greater risk of gingival bleeding on probing than those with short-term use of HAART $(P<0.05)$.

Using linear regression analysis, both unstimulated and stimulated salivary flow rates of HIV-infected subjects without HAART were found to be significantly higher than in those with short-term use of HAART $(P<0.05)$. In contrast, no statistically significant difference of salivary flow rates was observed between HIV-infected subjects with long-term use of HAART and those with short-term use of the medication. Of other four variables put in the model, none was statistically significant (Table 5).

\section{Discussion}

Our study demonstrated that oral health of HIV-infected subjects was improved with shortterm use of HAART. However, long-term use of HAART seemed to have adverse effects on oral health status of the subjects. A dramatic decrease in the prevalence of HIV-related oral lesions was observed in this study. Before the introduction of HAART, oral lesions were found in $82 \%$ of Thai people with AIDS (10). OC and OHL were shown to be the two most 
common oral lesions found in 54\% and $13 \%$ of Thai people with AIDS, respectively (10). However, in this study, OC and OHL were diagnosed in only $2 \%$ and $1 \%$ of HIV-infected subjects who received HAART, respectively. HIV-infected subjects who were not on HAART had a higher prevalence of OC compared with those on HAART. These findings are consistent with a UK cross-sectional study, which showed a higher prevalence of OC in adults not on any antiretroviral medication, compared with those on HAART (15).

It is well documented that frequency and severity of opportunistic diseases in HIV-infected subjects are decreased following the introduction of HAART (26). The frequency and characteristic of HIV-related oral manifestations have changed as a result of HAART (11, $15,16)$. Protease inhibitor therapy has been demonstrated to decrease both frequency and recurrence of OC in HIV-infected individuals (27). A decreased prevalence of OC with the advent of HAART was found to be associated with the use of PI. A study by Cauda et al. (28) $(n=93)$ reported that $7 \%$ of patients on PI had OC, compared with $36 \%$ of non-PItreated patients (28). Another study by Cassone et al. (29) reported that in two groups of HAART-naïve patients started either a PI-based HAART or an NNRTI-based HAART regimen, a significant decrease in episodes of OC and Candida carriage was observed in the PI group, but not in the NNRTI group. It has been proposed that the ability of PI to inhibit Candida infection may be related to similarities between candidal secreted aspartic proteinases (SAPs), which are the key virulence factors for Candida albicans, and HIV proteinase, and the inhibition of both by PI (30). However, a study by Patton et al. (11) found no significant difference in the prevalence of OC with the use of PI. In our study, most HIV-infected subjects received 2 NRTI +1 NNRTI, while only a few of them received PI. We did not find any association between the PI-based therapy and the presence of OC. This may be attributable to the low numbers of HIV-infected subjects receiving PI-based therapy and the low prevalence of OC in our study.

In our study, hyperpigmentation was found to be the most common oral complications observed in HIV-infected subjects who were on HAART. A study by Sharma et al. (31) also reported that melanotic hyperpigmentation was predominant in Indian patients on HAART $(P<0.05)$. This is not surprising as hyperpigmentation is a known side effect of HAART. Zidovudine can also give rise to mucocutaneous hyperpigmentation $(32,33)$.

Of interest, no oral warts were observed in our study. The lesions have never been reported from studies in other Asian countries $(31,34)$. In contrast, an increased prevalence of oral warts in subjects on HAART has been reported mainly from western countries $(11,35-38)$. An increase in benign human papilloma virus (HPV)-associated oral neoplastic lesions including papillomas, condylomas, and focal epithelial hyperplasia in patients on HAART has been observed $(11,35,39)$. However, in a Mexican population, similar detection rates of oral warts were documented in subjects on HAART compared with those who were not on therapy (16). Another study also reported that there was no change in the incidence of oral warts with the initiation of HAART (40). It has been proposed that the development of HPV-related oral mucosal lesions in HIV-infected individuals may be related to a decreased HIV viral load (37) and/or CD4 cell count $(37,41)$. The mechanism by which a reduction in HIV viral load may lead to an increased risk of oral warts remains unclear, but may represent a form of immune reconstitution syndrome $(37,42)$.

A previous study demonstrated that HPV, which is the cause of oral warts, is more commonly isolated from the oral cavity of HIV-infected individuals than from that of immunocompetent individuals (41). It remains unclear if long-term use of HAART will lead to an increased incidence of HPV-related oral malignancies, particularly if the HPV subtypes carried are high-risk subtypes such as HPV-16, which have been associated with oral malignancy (43). It is not known why oral warts are uncommon in Asian population. 
Further studies should be performed to determine whether there is a difference in the prevalence of oral HPV in Asian population compared with western people, which may imply a role for differences in genetics and host susceptibility to the virus.

In our study, HIV-infected subjects who were not on HAART showed greater risks of having orofacial pain, oral dryness, and oral lesions than those with HAART. A previous study by Patton et al. (44) reported that oral symptoms were frequently observed among HIV-infected individuals. Most people with HIV had oral discomfort that needed treatment (45). In addition, it has been reported that patients with HIV experienced more social impact of oral disease than did a comparable sample of the general population (46). The presence of oral symptoms has been shown to have a significant impact on health-related quality of life $(21,22)$. An improvement in oral health was significantly associated with improvements in both physical and mental health (22). Thus, the oral health-care professional plays an important role in improving and maintaining health-related quality of life in HIV-infected subjects.

Our study demonstrated that HIV-infected subjects who were not on HAART had a greater risk of having periodontal pockets of depth $\geq 4 \mathrm{~mm}$ than those with HAART. The prevalence of HIV-associated periodontal disease was reported to decrease significantly with HAART $(11,14,15,47)$. It has been reported that greater levels of periodontal destruction were associated with higher HIV viral loads (48). However, a biological explanation for the association remains unclear. Further extensive studies are needed to clarify these relationships.

In our study, HIV-infected subjects without HAART and those who were on long-term use of HAART seemed to have a greater risk of developing cervical caries than those with shortterm use of the medication. These findings are consistent with a previous study by Glick et al. (49) that revealed a relationship between HAART and increased risk of dental caries. However, a study by Phelan et al. (50) showed no significant difference in coronal or root caries by HIV status, nor did the results support a relationship between HAART and increased dental caries risk. In contrast, a study by Bretz et al. (51) reported that HIVinfected individuals receiving HAART had a lower occurrence of dental caries than did patients not taking these medications.

An association between decreased salivary flow and HAART has been reported as a factor for increased caries risk (52). Our results supported this finding because we found that both unstimulated and stimulated salivary flow rates of HIV-infected subjects with HAART were significantly lower than in those without HAART.

In our study, no salivary gland enlargement was observed in HIV-infected subjects receiving HAART. Before HAART era, no salivary gland enlargement was observed among Thai people with AIDS (10). Parotid gland enlargement had been infrequently observed in HIVinfected subjects in the developed world before the advent of HAART, with the prevalence rate of 5-10\% (53-55). With the introduction of HAART, previous studies in the developed countries reported that HIV-related salivary gland disease was increased $(11,39,40,56)$. A study by Patton et al. (11) reported a significant increase in the prevalence of HIVassociated salivary gland disease from 1.8\% to 5\%. A study by Navazesh et al. (57) demonstrated that PI-based HAART is a significant risk factor for developing enlarged salivary glands. In addition, the study indicated that women with an AIDS outcome were shown to have a $60 \%$ greater risk for having enlarged salivary glands (57). It has been shown that the glandular enlargement was correlated with decreased CD4 counts and advanced stages of HIV infection (58). Parotid gland swelling has been attributed to the increase in the CD8 lymphocyte count with CD8 lymphocytic infiltration into the intra- 
parotid lymph nodes in patients receiving HAART. In addition, intraparotid lymph nodes may undergo a significant hyper-plastic response and lead to visible parotid enlargement $(55,59)$.

In contrast, a study in developing countries reported that no changes in the prevalence of salivary gland enlargement were observed (16). A study by Nicolatou-Galitis et al. (47) reported that there was no change in the prevalence of salivary gland disease in HIVinfected individuals on PI-based HAART. Thus, it remains unclear whether salivary gland enlargement, especially of the parotid glands, is on the rise in HIV-infected individuals on HAART.

Saliva plays a significant role in oral and systemic health and its absence affects the quality of life. Individuals who suffer from salivary gland dysfunction are at risk for development of dental caries, periodontal diseases, and fungal infection (60). Xerostomia and salivary gland hypofunction have been shown to be associated with HIV infection $(17,19)$. In our study, salivary flow rates of both unstimulated and stimulated saliva were found to be significantly decreased in HIV-infected subjects compared with non-HIV controls. This may imply that salivary gland function can be compromised by HIV infection. This finding is consistent with that of our previous study, in which salivary flow rate of HIV-infected subjects in Thailand was found to be affected by HIV infection and was significantly decreased with advanced stage of the disease (19). A study by Navazesh et al. (52) also reported that HIVinfected women are at a significantly higher risk of xerostomia and salivary gland hypofunction than are non-infected women. A study by Lin et al. (18) revealed that salivary gland function is adversely affected in the early stage of HIV infection. Thus, a vigorous prophylactic regimen could be beneficial to prevent oral disease associated with reduced salivary gland function in this group of subjects.

In our study, both unstimulated and stimulated salivary flow rates of HIV-infected subjects who were on HAART were significantly lower than in those who were not on HAART. With the advent of HAART, a study by Navazesh et al. (57) revealed that PI-based HAART was significantly associated with a decrease in both unstimulated and stimulated salivary flow rates of HIV-infected subjects. Xerostomia and lipodystrophic changes of the salivary glands have been previously reported as potential adverse effects of PI therapy $(61,62)$. It is not known why PI-based HAART produces a significant decrease in the salivary flow rates. It has been proposed that the chemical structure of the PI may alter the structure and composition of saliva thereby decreasing the salivary flow (52). In contrast, a study by Lin et al. (63) revealed that no changes were observed in the salivary flow rates between HIVpositive men on HAART and those not on HAART. In our study, PI-based HAART was not found to be significantly associated with a decrease in salivary flow rates of the subjects. These contradictory findings may be a result of the differences in definition of a HAART user, the method of saliva collection, study design, and analysis of results in each study.

With respect to the feeling of oral dryness (xerostomia), HIV-infected subjects without HAART showed a greater risk of feeling dry in the mouth than those with short-term HAART. A previous study by Silverberg et al. (64) reported that prevalence of xerostomia was increased in patients who had discontinued HAART and those who had switched HAART regimens. Those patients with stable HAART showed the lowest prevalence of xerostomia (64). Similar findings were observed in a study by Navazesh et al. (57) where continued HAART usage for at least 6 months decreased the risk for developing a complaint of too little saliva.

In our study, CD4 cell count and viral load were not found to be significantly associated with salivary flow rates. A study by Navazesh et al. (57) indicated that the reduction in CD4 
cell counts and the increased HIV RNA levels were significantly associated with reduced salivary flow rates of HIV-infected individuals. It has been proposed that the lymphoproliferative response as a result of high levels of HIV p24 antigen may have been an important risk factor for developing reduced salivary flow rates (65-67). The exact nature of associated changes in salivary gland structure and function with HAART remains unknown. Further studies should be conducted to gain insights into the effects of long-term use of HAART on salivary gland structure and function.

\section{Acknowledgments}

This study was supported by NIH/NIDCR grant R21-DE-018340. S.T. was a scholar in the Royal Golden Jubilee PhD Program at the Faculty of Dentistry, Prince of Songkla University, Hat Yai, Thailand. The authors wish to thank Dr. Mostafa Nokta and Dr. Isaac Rodriguez-Chavez for encouragement in initiating this project, Prof. Dr. Beverly A. Dale for valuable advice on this proposal, Prof. Dr. Virasakdi Chongsuvivatwong and Dr. Alan Geater for helpful discussion on statistical analysis. Sincere thanks are extended to staff at Songklanagarind Hospital and Hat Yai Regional Hospital, and subjects in the study for their help and cooperation.

\section{References}

1. Li TS, Tubiana R, Katlama C, Calvez V, Ait Mohand H, Autran B. Long-lasting recovery in CD4 Tcell function and viral-load reduction after highly active antiretroviral therapy in advanced HIV-1 disease. Lancet. 1998; 351:1682-6. [PubMed: 9734884]

2. Lederman MM. Immune restoration and CD4+ T-cell function with antiretroviral therapies. AIDS. 2001; 15(Suppl. 2):S11-5. [PubMed: 11424971]

3. Hammer SM, Eron JJ Jr, Reiss P, et al. Antiretroviral treatment of adult HIV infection: 2008 recommendations of the international AIDS society USA panel. JAMA. 2008; 300:555-70. [PubMed: 18677028]

4. Ho DD. Time to hit HIV, early and hard. N Engl J Med. 1995; 333:450-1. [PubMed: 7616996]

5. Silvermann S Jr, Migliorati CA, Lozada-Nur F, Green-span D, Conant MA. Oral findings in people with or at a high risk for AIDS; a study of 375 homosexual males. J Am Dent Assoc. 1986; 112:187-92. [PubMed: 3485126]

6. Ramirez V, Gonzalez A, de la Rosa E, et al. Oral lesions in Mexican HIV-infected patients. J Oral Pathol Med. 1990; 19:482-5. [PubMed: 1962816]

7. Tukutuku K, Muyembe-Tamfum L, Kayembe K, Odio W, Kandi K, Ntumba M. Oral manifestations of AIDS in a heterosexual population in a Zaire hospital. J Oral Pathol Med. 1990; 19:232-4. [PubMed: 2359042]

8. Laskaris G, Hadjivassiliou M, Stratigos J. Oral signs and symptoms in 160 Greek HIV-infected patients. J Oral Pathol Med. 1992; 21:120-3. [PubMed: 1316436]

9. Glick M, Muzyka BC, Lurie D, et al. Oral manifestations associated with HIV-related disease as markers for immune suppression and AIDS. Oral Surg Oral Med Oral Pathol. 1994; 77:344-9. [PubMed: 8015797]

10. Nittayananta W, Chungpanich S. Oral lesions in a group of Thai people with AIDS. Oral Dis. 1997; 3(Suppl. 1):1-5. [PubMed: 9456639]

11. Patton LL, McKaig R, Strauss R, Rogers D, Eron JJ Jr. Changing prevalence of oral manifestations of human immune-deficiency virus in the era of protease inhibitor therapy. Oral Surg Oral Med Oral Pathol Oral Radiol Endod. 2000; 89:299-304. [PubMed: 10710453]

12. Nokta M. Oral manifestations associated with HIV infection. Curr HIV / AIDS Rep. 2008; 5:5-12. [PubMed: 18417029]

13. Miziara ID, Weber R. Oral lesions as predictors of highly active antiretroviral therapy failure in Brazilian HIV-infected children. J Oral Pathol Med. 2008; 37:99-106. [PubMed: 18197855]

14. Ceballos-Salobrena A, Gaitan-Cepeda LA, Ceballos-Garcia L, Lezama-Del Valle D. Oral lesions in HIV / AIDS patients undergoing highly active antiretroviral treatment including protease inhibitors: a new face of oral AIDS? AIDS Patient Care STDS. 2000; 14:627-35. [PubMed: 11119429] 
15. Tappuni AR, Fleming GJ. The effect of antiretroviral therapy on the prevalence of oral manifestations in HIV-infected patients: a UK study. Oral Surg Oral Med Oral Pathol Oral Radiol Endod. 2001; 92:623-8. [PubMed: 11740479]

16. Ramirez-Amador V, Esquivel-Pedraza L, Sierra-Madero J, Anaya-Saavedra G, Gonzalez-Ramirez L, Ponce-de-Leon S. The changing clinical spectrum of human immunodeficiency virus (HIV)related oral lesions in 1000 consecutive patients: a 12-year study in a referral center in Mexico. Medicine (Baltimore). 2003; 82:39-50. [PubMed: 12544709]

17. Navazesh M, Mulligan R, Komaroff E, Redford M, Greenspan D, Phelan J. The prevalence of xerostomia and salivary gland hypofunction in a cohort of HIV-positive and at-risk women. J Dent Res. 2000; 79:1502-7. [PubMed: 11005735]

18. Lin AL, Johnson DA, Stephan KT, Yeh CK. Alteration in salivary function in early HIV infection. J Dent Res. 2003; 82:719-24. [PubMed: 12939357]

19. Nittayananta W, Chanowanna N, Jealae S, Nauntofte B, Stoltze K. Hyposalivation, xerostomia and oral health status of HIV-infected subjects in Thailand before HAART era. J Oral Pathol Med. 2009 in press.

20. Ramos-Gomez FJ, Flaitz C, Catapano P, Murray P, Milnes AR, Dorenbaum A. Classification, diagnostic criteria, and treatment recommendations for orofacial manifestations in HIV-infected pediatric patients. Collaborative Workgroup on Oral Manifestations of Pediatric HIV Infection. J Clin Pediatr Dent. 1999; 23:85-96. [PubMed: 10204447]

21. Lorenz KA, Shapiro MF, Asch SM, Bozzette SA, Hays RD. Associations of symptoms and healthrelated quality of life: findings from a national study of persons with HIV infection. Ann Intern Med. 2001; 134:854-60. [PubMed: 11346321]

22. Coulter ID, Heslin KC, Marcus M, et al. Associations of self-reported oral health with physical and mental health in a nationally representative sample of HIV persons receiving medical care. Qual Life Res. 2002; 11:57-70. [PubMed: 12003056]

23. Chasombat S, McConnell MS, Siangphoe U, et al. National expansion of antiretroviral treatment in Thailand, 2000-2007: program scale-up and patient outcomes. J Acquir Immune Defic Syndr. 2009; 50:506-12. [PubMed: 19223784]

24. EC-Clearinghouse on Oral Problems Related to HIV Infection and WHO Collaborating Centre on Oral Manifestations of the Human Immunodeficiency Virus. Classification and diagnostic criteria for oral lesions in HIV infection. J Oral Pathol Med. 1993; 22:289-91. [PubMed: 8229864]

25. Navazesh M, Christensen CM. A comparison of whole mouth resting and stimulated salivary measurements procedures. J Dent Res. 1982; 61:1158-62. [PubMed: 6956596]

26. Powderly WG, Landay A, Lederman MM. Recovery of the immune system with antiretroviral therapy: the end of opportunism? J Am Med Assoc. 1998; 280:72-7.

27. Diz Dios P, Ocampo A, Miralles C, Otero I, Iglesias I, Rayo N. Frequency of oropharyngeal candidiasis in HIV-infected patients on protease inhibitor therapy. Oral Surg Oral Med Oral Pathol Oral Radiol Endod. 1999; 87:437-41. [PubMed: 10225625]

28. Cauda R, Tacconelli E, Tumbarello M, et al. Role of protease inhibitors in preventing recurrent oral candidosis in patients with HIV infection: a prospective case-control study. J Acquir Immune Defic Syndr. 1999; 21:20-5. [PubMed: 10235510]

29. Cassone A, Tacconelli E, De Bernardis F, et al. Anti-retroviral therapy with protease inhibitors has an early, immune reconstitution-independent beneficial effect on Candida virulence and oral candidiasis in human immunodeficiency virus-infected subjects. J Infect Dis. 2002; 185:188-95. [PubMed: 11807692]

30. Munro CA, ube B. Anti-fungal therapy at the HAART of viral therapy. Trends Microbiol. 2002; 10:173-7. [PubMed: 11912023]

31. Sharma G, Pai KM, Suhas S, Ramapuram JT, Doshi D, Anup N. Oral manifestations in HIV/AIDS infected patients from India. Oral Dis. 2006; 12:537-42. [PubMed: 17054765]

32. Greenberg RG, Berger TG. Nail and mucocutaneous hyperpigmentation with azidothymidine therapy. J Am Acad Dermatol. 1990; 22:327-30. [PubMed: 2303586]

33. Poizot-Martin I, Lafeuillade A, Dhiver C, et al. Cutaneo-mucosal hyperpigmentation in AIDS. 4 cases [in French]. Presse Med. 1991; 20:632-6. [PubMed: 1828567] 
34. Bendick C, Scheifele C, Reichart PA. Oral manifestations in 101 Cambodians with HIV and AIDS. J Oral Pathol Med. 2002; 31:1-4. [PubMed: 11896815]

35. Greenspan D, Canchola AJ, MacPhail LA, Cheikh B, Greenspan JS. Effect of highly active antiretroviral therapy on frequency of oral warts. Lancet. 2001; 357:1411-2. [PubMed: 11356441]

36. Greenwood I, Zakrzewska JM, Robinson PG. Changes in the prevalence of HIV-associated mucosal disease at a dedicated clinic over 7 years. Oral Dis. 2002; 8:90-4. [PubMed: 11991309]

37. King MD, Reznik DA, O'Daniels CM, Larsen NM, Osterholt D, Blumberg HM. Human papillomavirus-associated oral warts among human immunodeficiency virus-seropositive patients in the era of highly active antiretroviral therapy: an emerging infection. Clin Infect Dis. 2002; 34:641-8. [PubMed: 11803508]

38. Zakrzewska JM, Atkin PA. Oral mucosal lesions in a UK HIV/AIDS oral medicine clinic. A nine year, cross-sectional, prospective study. Oral Health Prev Dent. 2003; 1:73-9. [PubMed: 15643751]

39. Schmidt-Westhausen AM, Priepke F, Bergmann FJ, Reichart PA. Decline in the rate of oral opportunistic infections following introduction of highly active antiretroviral therapy. J Oral Pathol Med. 2000; 29:336-41. [PubMed: 10947250]

40. Greenspan D, Gange SJ, Phelan JA, et al. Incidence of oral lesions in HIV-1 infected women: reduction with HAART. J Dent Res. 2004; 83:145-50. [PubMed: 14742653]

41. Kreimer AR, Alberg AJ, Daniel R, et al. Oral human papillomavirus infection in adults is associated with sexual behavior and HIV serostatus. J Infect Dis. 2004; 189:686-98. [PubMed: 14767823]

42. Race EM, Adelson-Mitty J, Kriegel GR, et al. Focal mycobacterial lymphadenitis following initiation of protease-inhibitor therapy in patients with advanced HIV-1 disease. Lancet. 1998; 351:252-5. [PubMed: 9457095]

43. C'Decosta J, Saranath D, Dedhia P, Sanghvi V, Mehta AR. Detection of HPV-16 genome in human oral cancers and potentially malignant lesions from India. Oral Oncol. 1998; 34:413-20. [PubMed: 9861351]

44. Patton LL, Strauss RP, McKaig RG, Porter DR, Eron JJ Jr. Perceived oral health status, unmet needs, and barriers to dental care among HIV/AIDS patients in a North Carolina cohort: impacts of race. J Public Health Dent. 2003; 63:86-91. [PubMed: 12816138]

45. Arendorf TM, Bredekamp B, Cloete CA, Sauer G. Oral manifestations of HIV infection in 600 South African patients. J Oral Pathol Med. 1998; 27:176-9. [PubMed: 9563573]

46. Coates E, Slade GD, Goss AN, Gorkic E. ral conditions and their social impact among HIV dental patients. Aust Dent J. 1996; 41:33-6. [PubMed: 8639112]

47. Nicolatou-Galitis O, Velegraki A, Paikos S, et al. al. Effect of PI-HAART on the prevalence of oral lesions in HIV-I infected patients. A Greek study. Oral Dis. 2004; 10:145-50. [PubMed: 15089923]

48. Baqui AA, Meiller T, Jabra-Rizk M, Zhang M, Kelley J, Falkler W. Association of HIV viral load with oral diseases. Oral Dis. 1999; 5:294-8. [PubMed: 10561716]

49. Glick M, Berthold P, Danik J. Severe caries and the use of protease inhibitors (abstract). J Dent Res. 1998; 77:84.

50. Phelan JA, Mulligan R, Nelson E, et al. Dental caries in HIV-seropositive women. J Dent Res. 2004; 83:869-73. [PubMed: 15505238]

51. Bretz WA, Flaitz C, Moretti A, Corby P, Schneider LG, Nichols CM. Medication usage and dental caries outcome-related variables in HIV/AIDS patients. AIDS Patient Care STDs. 2000; 14:549_ 54. [PubMed: 11054939]

52. Navazesh M, Mulligan R, Barron Y, et al. A 4-year longitudinal evaluation of xerostomia and salivary gland hypofunction in the Women's Interagency HIV Study participants. Oral Surg Oral Med Oral Pathol Oral Radiol Endod. 2003; 95:693-8. [PubMed: 12789150]

53. Schiodt M, Greenspan D, Daniels TE, et al. Parotid gland enlargement and xerostomia associated with labial sialadenitis in HIV-infected patients. J Autoimmun. 1989; 2:415-25. [PubMed: 2789646] 
54. Soberman N, Leonidas JC, Berdon WE, et al. Parotid enlargement in children seropositive for human immunodeficiency virus: imaging findings. AJR Am J Roentgenol. 1991; 157:553-6. [PubMed: 1651645]

55. Mandel L, Surattanont F. Regression of HIV parotid swellings after antiviral therapy: case reports with computed tomographic scan evidence. Oral Surg Oral Med Oral Pathol Oral Radiol Endod. 2002; 94:454-9. [PubMed: 12374919]

56. Reichart P. US1 HIV - changing patterns in HAART era, patients' quality of life and occupational risks. Oral Dis. 2006; 12(Suppl. 1):3.

57. Navazesh M, Mulligan R, Karim R, et al. Effect of HAART on salivary gland function in the Women's Interagency HIV Study (WIHS). Oral Dis. 2009; 15:52-60. [PubMed: 19017280]

58. Vargas PA, Mauad T, Bohm GM, Saldiva PH, Almeida OP. Parotid gland involvement in advanced AIDS. Oral Dis. 2003; 9:55-61. [PubMed: 12657029]

59. Itescu S, Brancato LJ, Buxbaum J, et al. A diffuse infiltrative CD8 lymphocytosis syndrome in human immunodeficiency virus (HIV) infection: a host immune response associated with HLADR5. Ann Intern Med. 1990; 112:3-10. [PubMed: 2136714]

60. Navazesh M, Denny P, Sobel S. Saliva: a fountain of opportunity. J Calif Dent Assoc. 2002; 30:783-8. [PubMed: 12403483]

61. Olive A, Salavert A, Manriquez M, Clotet B, Moragas A. Parotid lipomatosis in HIV positive patients: a new clinical disorder associated with protease inhibitors. Ann Rheum Dis. 1998; 57:749. [PubMed: 10070278]

62. Scully C, Diz Dios P. Orofacial effects of antiretroviral therapies. Oral Dis. 2001; 7:205-10. [PubMed: 11575869]

63. Lin AL, Johnson DA, Sims CA, Stephan KT, Yeh CK. Salivary gland function in HIV-infected patients treated with highly active antiretroviral therapy (HAART). Oral Surg Oral Med Oral Pathol Oral Radiol Endod. 2006; 102:318-24. [PubMed: 16920540]

64. Silverberg MJ, Gore ME, French AL, et al. Prevalence of clinical symptoms associated with highly active antiretroviral therapy in the Women's Interagency HIV Study. Clin Infect Dis. 2004; 39:717-24. [PubMed: 15356788]

65. Bruner JM, Cleary KR, Smith FB, Batsakis JG. Immunocytochemical identification of HIV (p24) antigen in parotid lymphoid lesions. J Laryngol Otol. 1989; 103:1063-6. [PubMed: 2514236]

66. Vicandi B, Jimenez-Heffernan JA, Lopez-Ferrer P, et al. HIV-1 (p24)-positive multinucleated giant cells in HIV-associated lymphoepithelial lesion of the parotid gland. A report of two cases. Acta Cytol. 1999; 43:247-51. [PubMed: 10097719]

67. Uccini S, D'Offizi G, Angelici A, et al. Cystic lymphoepithelial lesions of the parotid gland in HIV-1 infection. AIDS Patient Care STDs. 2000; 14:143-7. [PubMed: 10763543] 
Table 1

Demographic data and characteristics of HIV-infected subjects with and without HAART and non-HIV individuals

\begin{tabular}{|c|c|c|c|c|}
\hline \multirow[b]{3}{*}{ Variables } & \multicolumn{3}{|c|}{ HIV-infected subjects } & \multirow[b]{3}{*}{$\begin{array}{l}\text { Non-HIV subjects }(n= \\
\text { 50) }\end{array}$} \\
\hline & \multirow[b]{2}{*}{ No HAART $(n=58)$} & \multicolumn{2}{|c|}{ With HAART $(\mathrm{n}=99)$} & \\
\hline & & $\begin{array}{l}\text { Short-term HAART }(<3 \\
\text { years })(n=45)\end{array}$ & $\begin{array}{l}\text { Long-term HAART }(\geq 3 \\
\text { years })(n=54)\end{array}$ & \\
\hline \multicolumn{5}{|l|}{ Age (years) } \\
\hline Mean & 34 & 37 & 40 & 36 \\
\hline Range & $20-59$ & $23-57$ & $27-53$ & $19-59$ \\
\hline \multicolumn{5}{|l|}{ Gender } \\
\hline Male & $20(34.5 \%)$ & $18(40 \%)$ & $33(61.1 \%)$ & $25(50 \%)$ \\
\hline Female & $38(65.5 \%)$ & $27(60 \%)$ & $21(38.9 \%)$ & $25(50 \%)$ \\
\hline \multicolumn{5}{|l|}{ Marital status } \\
\hline Single & $13(23.6 \%)$ & $5(15.2 \%)$ & $13(31.7 \%)$ & $21(42 \%)$ \\
\hline Married & $33(60.0 \%)$ & $17(51.5 \%)$ & $16(39.0 \%)$ & $27(54 \%)$ \\
\hline Divorced & $4(7.3 \%)$ & $7(21.2 \%)$ & $7(17.1 \%)$ & $0(0 \%)$ \\
\hline Widowed & $5(9.1 \%)$ & $4(12.1 \%)$ & $5(12.2 \%)$ & $2(4 \%)$ \\
\hline \multicolumn{5}{|l|}{ Religion } \\
\hline Buddhism & $56(96.6 \%)$ & $42(93.3 \%)$ & $51(94.4 \%)$ & $24(48 \%)$ \\
\hline Islam & $2(3.4 \%)$ & $3(6.7 \%)$ & $3(5.6 \%)$ & $26(52 \%)$ \\
\hline \multicolumn{5}{|l|}{ Highest education } \\
\hline Primary school level & $33(56.9 \%)$ & $15(33.3 \%)$ & $12(22.2 \%)$ & $24(48 \%)$ \\
\hline Secondary school level & $10(20 \%)$ & $16(35.6 \%)$ & $21(38.9 \%)$ & $10(20 \%)$ \\
\hline Polytechnic level & $2(3.4 \%)$ & $4(8.9 \%)$ & $10(18.5 \%)$ & $3(6 \%)$ \\
\hline University level & $4(6.9 \%)$ & $9(20.0 \%)$ & $9(16.7 \%)$ & $11(22 \%)$ \\
\hline Other & $1(1.7 \%)$ & $1(2.2 \%)$ & $2(3.7 \%)$ & $2(4 \%)$ \\
\hline \multicolumn{5}{|l|}{ Occupation } \\
\hline Employee & $21(42 \%)$ & $23(51.1 \%)$ & $21(38.9 \%)$ & $21(42 \%)$ \\
\hline Trading & $6(10.3 \%$ & $5(11.1 \%)$ & $2(3.7 \%)$ & $4(8 \%)$ \\
\hline Agriculture & $3(5.2 \%)$ & $2(4.4 \%)$ & $1(1.9 \%)$ & $8(16 \%)$ \\
\hline Government servant & $0(0.0 \%)$ & $2(4.4 \%)$ & $9(16.7 \%)$ & $2(4 \%)$ \\
\hline Student & $1(1.7 \%)$ & $0(0.0 \%)$ & $0(0.0 \%)$ & $8(16 \%)$ \\
\hline Others & $14(24.1 \%)$ & $12(26.7 \%)$ & $17(31.5 \%)$ & $7(14 \%)$ \\
\hline Unemployed & $3(5.2 \%)$ & $1(2.2 \%)$ & $4(7.4 \%)$ & $0(0 \%)$ \\
\hline \multicolumn{5}{|l|}{ Income (Baht)/month } \\
\hline$<5000$ & $25(43.1 \%)$ & $18(40.0 \%)$ & $13(24.5 \%)$ & $23(46 \%)$ \\
\hline $5000-10000$ & $26(44.8 \%)$ & $17(37.8 \%)$ & $19(35.8 \%)$ & $22(44 \%)$ \\
\hline $10001-20000$ & $7(12.1 \%)$ & $6(13.3 \%)$ & $11(20.8 \%)$ & $5(10 \%)$ \\
\hline $20001-30000$ & $0(0.0 \%)$ & $2(4.4 \%)$ & $6(11.3 \%)$ & $0(0 \%)$ \\
\hline$>30000$ & $0(0.0 \%)$ & $2(4.4 \%)$ & $4(7.5 \%)$ & $0(0 \%)$ \\
\hline \multicolumn{5}{|l|}{ Risk group } \\
\hline Sex with person with HIV & $43(74.1 \%)$ & $30(66.7 \%)$ & $41(75.9 \%)$ & - \\
\hline
\end{tabular}




\begin{tabular}{|c|c|c|c|c|}
\hline \multirow[b]{3}{*}{ Variables } & \multicolumn{3}{|c|}{ HIV-infected subjects } & \multirow[b]{3}{*}{$\begin{array}{l}\text { Non-HIV subjects }(n= \\
\text { 50) }\end{array}$} \\
\hline & \multirow[b]{2}{*}{ No HAART (n = 58) } & \multicolumn{2}{|c|}{ With HAART (n = 99) } & \\
\hline & & $\begin{array}{l}\text { Short-term HAART ( }<3 \\
\text { years) }(n=45)\end{array}$ & $\begin{array}{l}\text { Long-term HAART }(\geq 3 \\
\text { years) }(n=54)\end{array}$ & \\
\hline Commercial sex worker & $4(6.9 \%)$ & $2(4.4 \%)$ & $3(5.6 \%)$ & - \\
\hline Men who have sex with men & $3(5.2 \%)$ & $2(4.4 \%)$ & $3(5.6 \%)$ & - \\
\hline Intravenous drug user & $2(3.4 \%)$ & $7(15.6 \%)$ & $3(15.6 \%)$ & - \\
\hline Blood transfusion & $1(1.7 \%)$ & $0(0.0 \%)$ & $1(1.9 \%)$ & - \\
\hline Other & $5(8.6 \%)$ & $4(8.9 \%)$ & $3(5.6 \%)$ & - \\
\hline \multicolumn{5}{|l|}{ Duration of HIV infection (years) } \\
\hline Mean & 3.8 & 4.8 & 8.8 & - \\
\hline Range & $0.1-16$ & $0.4-15$ & $3-24$ & - \\
\hline \multicolumn{5}{|l|}{ Smoking habit } \\
\hline Smoker & $39(67.2 \%)$ & $16(35.6 \%)$ & $18(33.3 \%)$ & $34(68 \%)$ \\
\hline Non-smoker & $19(32.8 \%)$ & $29(64.4 \%)$ & $36(66.7 \%)$ & $16(32 \%)$ \\
\hline \multicolumn{5}{|l|}{ Alcohol consumption } \\
\hline Drinker & $34(68 \%)$ & $12(26.7 \%)$ & $13(24.1 \%)$ & $34(68 \%)$ \\
\hline Non-drinker & $21(36.2 \%)$ & $33(73.3 \%)$ & $41(75.9 \%)$ & $16(32 \%)$ \\
\hline \multicolumn{5}{|c|}{ Presence of HIV-related systemic diseases } \\
\hline Yes & $15(25.9 \%)$ & $14(34.1 \%)$ & $9(18.8 \%)$ & - \\
\hline No & $43(74.1 \%)$ & $27(65.9 \%)$ & $39(81.2 \%)$ & - \\
\hline \multicolumn{5}{|l|}{ Oral hygiene } \\
\hline Good & $1(1.7 \%)$ & $3(6.7 \%)$ & $0(0.0 \%)$ & $1(2 \%)$ \\
\hline Fair & $35(60.3 \%)$ & $23(51.1 \%)$ & $31(57.4 \%)$ & $27(54 \%)$ \\
\hline Poor & $22(37.9 \%)$ & $19(42.2 \%)$ & $23(42.6 \%)$ & $23(42.6 \%)$ \\
\hline \multicolumn{5}{|c|}{ Total lymphocyte cell counts (cell//mm³) } \\
\hline$<1000$ & $9(16.7 \%)$ & $12(26.7 \%)$ & $6(11.1 \%)$ & - \\
\hline $1000-2000$ & $22(40.7 \%)$ & $14(31.1 \%)$ & $14(25.9 \%)$ & - \\
\hline$>2000$ & $23(42.6 \%)$ & $19(42.2 \%)$ & $34(63.0 \%)$ & - \\
\hline \multicolumn{5}{|l|}{ CD4 cell counts (cell $/ \mathrm{mm}^{3}$ ) } \\
\hline Mean & 245.5 & 250.1 & 530.7 & - \\
\hline Range & $5-669$ & $9-630$ & $74-1600$ & - \\
\hline \multicolumn{5}{|l|}{ Viral load (copies) } \\
\hline Mean & 782.6 & 21560 & 5627 & - \\
\hline Range & 0-30 100 & $50-750000$ & $50-139000$ & - \\
\hline
\end{tabular}


Table 2

Prevalence of oral lesions in HIV-infected subjects with and without HAART and in non-HIV-infected individuals

\begin{tabular}{|c|c|c|c|c|}
\hline \multirow[b]{3}{*}{ Oral lesions } & \multicolumn{3}{|c|}{ HIV-infected subjects } & \multirow[b]{3}{*}{$\begin{array}{l}\text { Non-HIV individuals } \\
\quad(\mathbf{n}=\mathbf{5 0})\end{array}$} \\
\hline & \multirow[b]{2}{*}{$\underset{58)}{\text { No HAART }}(\mathbf{n}=$} & \multicolumn{2}{|c|}{ With HAART $(n=99)$} & \\
\hline & & $\begin{array}{c}\text { Short-term HAART } \\
(<3 \text { years })(n=45)\end{array}$ & $\begin{array}{c}\text { Long-term HAART }(\geq 3 \\
\text { years) }(n=54)\end{array}$ & \\
\hline Absence of oral lesions & $28(48 \%)$ & $20(44 \%)$ & $23(43 \%)$ & $33(66 \%)$ \\
\hline Presence of oral lesions ${ }^{a}$ & $30(52 \%)$ & $25(56 \%)$ & $31(57 \%)$ & $17(34 \%)$ \\
\hline Hyperpigmentation & $16(28 \%)$ & $19(35 \%)$ & $25(46 \%)$ & $15(30 \%)$ \\
\hline Denture stomatitis & $5(9 \%)$ & $4(9 \%)$ & $4(7 \%)$ & $1(2 \%)$ \\
\hline Erythematous candidiasis & $4(7 \%)$ & $0(0 \%)$ & $0(0 \%)$ & $0(0 \%)$ \\
\hline Pseudomembranous candidiasis & $1(2 \%)$ & $2(4 \%)$ & $0(0 \%)$ & $0(0 \%)$ \\
\hline Hairy leukoplakia & $3(5 \%)$ & $0(0 \%)$ & $1(2 \%)$ & $0(0 \%)$ \\
\hline Aphthous ulcers & $2(3 \%)$ & $2(4 \%)$ & $1(2 \%)$ & $2(4 \%)$ \\
\hline Linear gingival erythema & $2(3 \%)$ & $1(2 \%)$ & $0(0 \%)$ & $0(0 \%)$ \\
\hline Traumatic ulcers & $0(0 \%)$ & $1(2 \%)$ & $0(0 \%)$ & $0(0 \%)$ \\
\hline Frictional hyperkeratosis & $0(0 \%)$ & $1(2 \%)$ & $1(2 \%)$ & $0(0 \%)$ \\
\hline Smoker hyperkeratosis & $0(0 \%)$ & $1(2 \%)$ & $1(2 \%)$ & $0(0 \%)$ \\
\hline
\end{tabular}

${ }^{a}$ Some subjects had more than one lesion. 


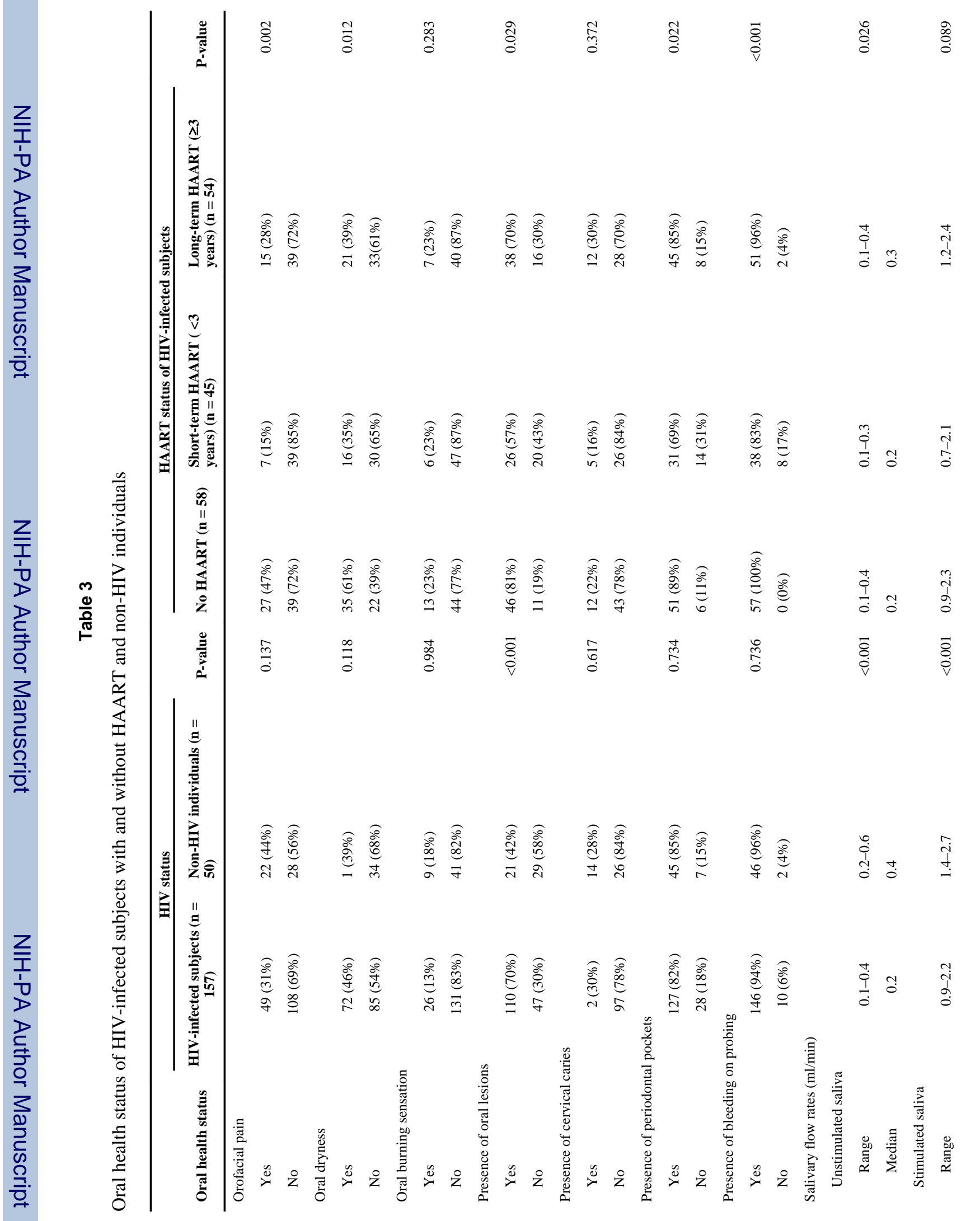




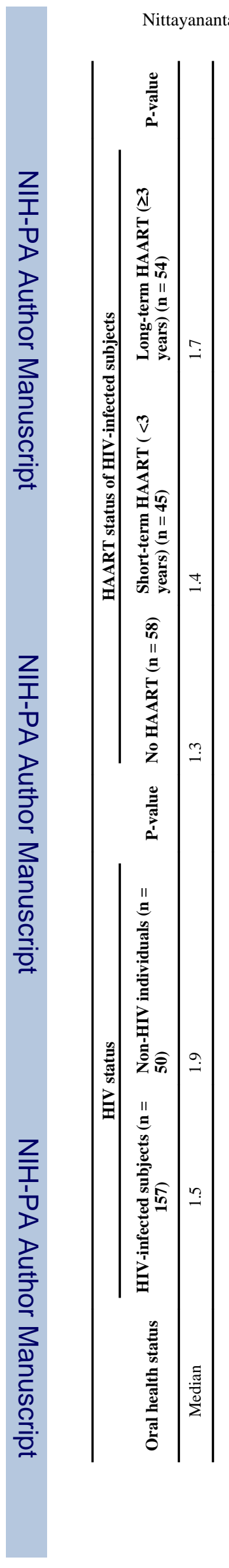

Page 16 
Table 4

Effects of long-term use of HAART on oral health status of HIV-infected subjects based on logistic regression $^{a}$

\begin{tabular}{llc}
\hline & \multicolumn{2}{c}{ Adjusted odds ratios (95\% confidence interval) } \\
\cline { 2 - 3 } Oral health status & No HAART & Long-term use of HAART \\
\hline Orofacial pain & $4.88(1.81,13.2)^{* *}$ & $1.39(0.45,4.26)$ \\
Oral dryness & $3.5(1.49,8.26)^{* *}$ & $1.12(0.45,2.83)$ \\
Oral burning sensation & $1.78(0.59,5.32)$ & $0.84(0.22,3.15)$ \\
Oral hygiene status & $0.84(0.33,2.14)$ & $1.57(0.57,4.33)$ \\
Presence of oral lesions & $4(1.5,10.69)^{* *}$ & $2.84(1.06,7.61)^{*}$ \\
Presence of periodontal pockets & $4.67(1.56,13.99)^{* *}$ & $2.92(0.96,8.87)$ \\
Presence of cervical caries & $1.71(0.49,6.01)$ & $2.45(0.61,9.82)$ \\
\hline${ }^{a}$ After controlling for duration of HIV infection, CD4 cell count, smoking habit, and alcohol consumption. \\
${ }_{\text {Short-term HAART was used as a reference. }}$ \\
${ }_{P}^{*}$-value < 0.05.
\end{tabular}


Table 5

Effects of long-term use of HAART and other variables on salivary flow rates of HIV-infected subjects

\begin{tabular}{|c|c|c|}
\hline \multirow[b]{2}{*}{ Predictors for salivary flow rate } & \multicolumn{2}{|c|}{ Adjusted coefficient ( $95 \%$ confidence interval) } \\
\hline & Unstimulated salivary flow rate & Stimulated salivary flow rate \\
\hline \multicolumn{3}{|c|}{ Duration of HAART $($ reference $=$ short-term HAART $)$} \\
\hline No HAART & $0.15(0.03,0.27)^{*}$ & $0.59(0.08-1.1)^{*}$ \\
\hline Long-term HAART & $0.06(-0.07,0.19)$ & $0.2(-0.36-0.76)$ \\
\hline \multicolumn{3}{|c|}{ Duration of HIV infection (reference $=<5$ year) } \\
\hline $5-10$ years & $0(-0.11,0.11)$ & $0.45(0,0.9)$ \\
\hline$>10$ years & $-0.08(-0.25,0.09)$ & $-0.17(-0.89,0.55)$ \\
\hline \multicolumn{3}{|c|}{$\mathrm{CD} 4$ count $\left(\right.$ reference $\left.=>200 \mathrm{cell} / \mathrm{cm}^{3}\right)$} \\
\hline$<200$ & $-0.11(-0.22,0)$ & $0.15(-0.32,0.63)$ \\
\hline \multicolumn{3}{|l|}{ Smoking } \\
\hline Yes vs. no & $0.03(-0.09,0.15)$ & $0.26(-0.25,0.77)$ \\
\hline \multicolumn{3}{|l|}{ Alcohol } \\
\hline Yes vs. no & $0.08(-0.04,0.21)$ & $0.13(-0.41,0.66)$ \\
\hline
\end{tabular}

${ }^{*} P$-value $<0.05$. 